\author{
Magdalena Lidia Boczoń \\ Uniwersytet Gdański
}

\title{
Bogdan Nawroczyński jako publicysta „Kultury i Wychowania” w latach 1933-1939
}

Okres dwudziestolecia międzywojennego obfitował w twórczy entuzjazm na wielu płaszczyznach życia. Odzyskaniu przez Polskę niepodległości w roku 1918 towarzyszyła nadzieja na odbudowę kraju zarówno pod względem politycznym, jak i kulturalnym. Również na polu nauk społecznych, w tym także pedagogiki, toczyły się zacięte spory związane z różnego rodzaju problematyką wychowawczo-oświatową. Dowodem na to jest m. in., niespotykana już dziś, liczba tytułów, popularność i rola czasopism pedagogicznych ${ }^{1}$. To właśnie na ich łamach spierali się ówcześni myśliciele, naukowcy, w tym także pedagodzy oraz nauczyciele praktycy, którym tematyka wychowania była szczególnie bliska. Jednym z takich periodyków, adresowanym przede wszystkim do inteligencji o orientacji humanistycznej był, wydawany w latach 1933-1939, kwartalny dodatek do „Przeglądu Pedagogicznego” - „Kultura i Wychowanie”. W tymże czasopiśmie, pośród wielu znamienitych dla polskiej kultury i pedagogiki twórców, takich jak np. Ludwik Chmaj, Władysław Tatarkiewicz, Sergiusz Hessen czy Stefan Szuman, publikował również Bogdan Nawroczyński.

Prawdą jest, iż wkład Bogdana Nawroczyńskiego w publicystykę i polemikę pedagogiczną „Kultury i Wychowania” ogranicza się wyłącznie do czterech artykułów, z czego zaledwie dwa wydają się bezpośrednio prezentować poglądy autora. Niemniej jednak, stanowią one mocny głos w toczących się w owym czasie burzliwych dyskusjach. Są także istotne z perspektywy profilu omawianego czasopisma. Jasno bowiem zarysowany charakter „Kultury i Wychowania”, przejawiający się w idei pluralizmu światopoglądowego i dialogu różnych orientacji w duchu wartości kulturalnych, kwalifikował je jako czołowy periodyk propagujący idee filozofii i pedagogiki kultury ${ }^{2}$. Na jego łamach krystalizowały się zadania i podwaliny teoretyczne tego, rozwijającego się dopiero wówczas w Polsce, nurtu. Bogdan Nawroczyński zaś był w okresie II Rzeczypospolitej, obok Sergiusza Hessena i Bogdana Suchodolskiego, jednym z głównych przedstawicieli tego nurtu w wychowaniu.

\footnotetext{
${ }^{1}$ B. Truchlińska, Filozofia kultury Bogdana Suchodolskiego, Lublin 2006, s. 161.

${ }^{2}$ Tamże.
} 
Jednakże publicystyka Nawroczyńskiego w „Kulturze i Wychowaniu” nie została dotąd omówiona w literaturze historiograficznej. Dlatego też tematyka niniejszego artykułu koncentrować się będzie właśnie na tym aspekcie jego twórczości.

Artykuł podzielony został na cztery części dotyczące kolejno: charakterystyki „Kultury i Wychowania”; tematyki artykułów Nawroczyńskiego w omawianym periodyku; publicystyki Nawroczyńskiego w „Kulturze i Wychowaniu” na tle jego twórczości i praktyki zawodowej w okresie międzywojnia oraz wkładu Nawroczyńskiego w dorobek pedagogiki kultury w okresie II Rzeczypospolitej zawarty w artykułach opublikowanych w omawianym czasopiśmie.

\section{1. „Kultura i Wychowanie"}

„Kultura i Wychowanie" nie było to wprawdzie czasopismo ukazujące się samodzielnie, jednak prezentowana na jego kartach jakość merytoryczna pozwala za takowe je uważać ${ }^{3}$. Bogumiła Truchlińska w swym artykule pod tytułem Przeszłość - przyszłości. „Kultura i Wychowanie” jako pismo dialogu intelektualnego w ten sposób wyraziła się o tym kwartalniku:

Na łamach „Kultury i Wychowania” dokonywał się proces intelektualny, który określamy dziś mianem dialogu. Decydowała tu nie tylko otwartość pisma, ale i gotowość ludzi o różnych orientacjach światopoglądowych i politycznych do wymiany poglądów ${ }^{4}$.

Nad poziomem druku czuwał przez pierwszy rok Henryk Galle, później zaś, już do końca istnienia pisma, Bogdan Suchodolski. Pismo spełniało nie tylko funkcję periodyku naukowego i specjalistycznego czy też informacyjnego, ale także w dużej mierze wychowawczego i sprzyjającego samokształceniu. Ambicją „Kultury i Wychowania" była realizacja, wyznaczonych przez redakcję, szczytnych i niełatwych do urzeczywistnienia zadań. Należały do nich przede wszystkim:

- dyskusja nad współczesnymi autorom problemami społecznymi, filozoficznymi i pedagogicznymi, takimi jak: kryzys kultury i sposoby jego przezwyciężenia, przekształcenie pracy w pracę twórczą, upowszechnienie i uspołecznienie kultury, w tym także problematyka metod wychowania i kształcenia całego społeczeństwa ${ }^{5}$;

- zapoznanie czytelników z zagraniczną myślą pedagogiczną i filozoficzną;

- orientacja w dorobku przeszłości, w tym twórczości myślicieli poprzednich pokoleń;

${ }^{3}$ Tamże.

${ }^{4}$ B. Truchlińska, Przeszłość - przyszłości. „Kultura i Wychowanie” jako pismo dialogu intelektualnego, [w:] Pedagogika kultury. Historyczne osiagnięcia, wspótczesne kontrowersje wokót edukacji kulturalnej perspektywy rozwoju, red. J. Gajda, Lublin 1998, s. 386.

${ }^{5}$ B. Truchlińska, Filozofia kultury..., s. 162. 
- określenie roli i znaczenia szeroko pojmowanej kultury;

- (pośrednio także) konstruowanie teoretycznych podwalin pedagogiki kultury.

\section{Artykuły Bogdana Nawroczyńskiego w „Kulturze i Wychowaniu”}

Swoją aktywność pisarską w „Kulturze i Wychowaniu” Nawroczyński rozpoczął artykułem z roku 1936, zawartym w zeszycie trzecim, pod tytułem: Trzej przedstawiciele pedagogiki pozytywnej w Polsce. Myślicielami, którym poświęcił ów artykuł byli Henryk Wernic, Adolf Dygasiński oraz Jan Władysław Dawid.

Drugi artykuł Nawroczyńskiego, pod tytułem Pedagogika narodowa w latach 1880-1925, opublikowany został w roku 1937, w zeszycie pierwszym. Po raz kolejny autor dokonywał prezentacji poglądów trzech myślicieli. Tym razem przybliżył sylwetki Stanisława Prusa Szczepanowskiego, Zygmunta Balickiego oraz Lucjana Zarzeckiego.

Kolejną publikacją Nawroczyńskiego, zamieszczoną w tymże samym roku, w drugim zeszycie, był króciutki artykuł zatytułowany Kształcenie nauczycieli. Zostało w nim bezpośrednio wyrażonych najwięcej myśli autora, a poza tym tematyka jego wypowiedzi dotyczy zadań, które w owym czasie próbował realizować.

Swój ostatni artykuł w „Kulturze i Wychowaniu” Nawroczyński opublikował w roku 1938, w zeszycie pierwszym. Tekst zatytułowany był Dwa realizmy pedagogiczne i stanowił porównanie i ustosunkowanie się autora do dwóch różnych publikacji dotyczących tego samego tematu - realizmu pedagogicznego. Przedmiotem porównania stały się artykuł Bogdana Suchodolskiego pod tytułem: Wychowanie realistyczne oraz Ludwika Chmaja zatytułowany Granice realizmu w wychowaniu. Nawroczyński słusznie zauważył, iż obaj myśliciele różnie definiowali realizm pedagogiczny, co często w literaturze pedagogicznej jest przyczyną nieporozumień. Suchodolski określał wychowanie realistyczne jako „kształcenie człowieka z związku z realnymi zadaniami, które jako obywatel i zawodowiec będzie musiał podjąć i wykonywać w życiu". Chmaj natomiast uważał, iż jest ono „przystosowaniem dziecka do rzeczywistości”, rozumianym jako „takie jego urabianie i ukształtowanie, by mogło całkowicie podołać jej wymaganiom"'.

W przytoczonych powyżej artykułach Nawroczyński realizował następujące z zadań „Kultury i Wychowania:

- orientacja $\mathrm{w}$ dorobku przeszłych pokoleń poprzez poszukiwanie źródeł współczesnej autorowi myśli pedagogicznej i filozoficznej;

\footnotetext{
${ }^{6}$ B. Nawroczyński, Dwa realizmy pedagogiczne, „Kultura i Wychowanie” 1938, z. 1, s. 14.

${ }^{7}$ Tamże, s. 15.
} 
- dyskusja nad bieżącą w owym czasie problematyką: kształcenie społeczeństwa i kształcenie nauczycieli (wychowawców);

- konstruowanie teoretycznych podwalin pedagogiki kultury (o czym będzie mowa w dalszej części artykułu).

\section{Publicystyka w ,Kulturze i Wychowaniu” na tle caloksztaltu twórczości i pracy zawodowej Bogdana Nawroczyńskiego}

Lata międzywojenne były dla Bogdana Nawroczyńskiego okresem intensywnej pracy naukowej i pedagogicznej w placówkach edukacyjnych, co zaowocowało najważniejszymi dziełami pedagogicznymi w jego życiu. Chociaż prym wiedzie pośród nich praca z roku 1930 pod tytułem Zasady nauczania, inne jego publikacje również zasługują na uwagę. W tym okresie Nawroczyński rozpoczął też walkę o reformę w szkolnictwie i właściwe kształcenie nauczycieli. Działania tego typu podejmował początkowo jako wizytator ministerialny Wydziału Programowego oraz wykładowca w Państwowym Instytucie Pedagogicznym ${ }^{8}$, później zaś jako profesor Uniwersytetu Poznańskiego i wreszcie Uniwersytetu Warszawskiego'.

Problematyka podjęta przez Nawroczyńskiego w „Kulturze i Wychowaniu” zamyka się w kilku następujących punktach:

1. Polemika z ideałami romantyzmu i pozytywizmu (idealizm a realizm).

2. Przywołanie poglądów pedagogów z poprzedniego pokolenia oraz konfrontacja $\mathrm{z}$ ich twórczością.

3. Dyskusja nad zagadnieniem kształcenia nauczycieli.

Kwestia antynomii ideałów romantycznych i pozytywistycznych pojawiła się w twórczości Nawroczyńskiego dwukrotnie: w artykule przybliżającym przedstawicieli pedagogiki narodowej oraz, w nieco późniejszym tekście pod tytułem Dwa realizmy pedagogiczne. Choć pozornie tytuły nie wskazują na zbieżność tematyczną, to w rzeczywistości obie publikacje zmierzały ku wspólnym wnioskom. Główną różnicą miedzy nimi jest fakt, iż w pierwszej autor wyrażał swoje poglądy pośrednio, za pomocą analizy i krytyki twórczości innych pedagogów; w drugiej zaś bezpośrednio zapoznając czytelnika ze swoim zdaniem w omawianej kwestii. Mylące może być również zróżnicowane nazewnictwo. W pierwszym artykule bowiem, przy okazji omawiania poglądów Szczepanowskiego mowa jest o ideałach romantyzmu i pozytywizmu, podczas gdy w artykule drugim autor posługuje się odmienną terminologią, konfrontując idealizm z realizmem. Jednakże

\footnotetext{
${ }^{8}$ W. Okoń, Bogdan Nawroczyński - nauczyciel nauczycieli, [w:] tenże, Wizerunki sławnych pedagogów polskich, Warszawa 1993, s. 303.

${ }^{9}$ J. Hellwig, Bogdan Nawroczyński (1882-1974), [w:] Dzieje historii wychowania w Polsce i jej twórcy, Poznań 2001, s. 175-177.
} 
realizm był właśnie celem pedagogiki pozytywistycznej, a idealizm - romantycznej. Zdecydowanie zatem tematyka jest analogiczna, co potwierdzają identyczne wnioski poczynione przez autora. Próbował on zwrócić uwagę czytelnika na potrzebę umiaru w wychowaniu poprzez zwalczenie antynomii realizmu i idealizmu. Zalecał ciągłe utrzymywanie napięcia pomiędzy obiema opcjami broniąc stanowiska, iż w procesie wychowania należy unikać wszelkich skrajności, co jest charakterystycznym poglądem dla przedstawiciela pedagogiki kultury okresu międzywojennego. W jego opinii wykluczyć z wychowania należy zarówno ciasny i ekskluzywny realizm ontologiczny, jak i daleki idealizm, nie mający poparcia w rzeczywistości.

Drugim wyzwaniem, jakie podjął Nawroczyński w „Kulturze i Wychowaniu”, było przywołanie dorobku naukowego pedagogów poprzedniego pokolenia oraz konfrontacja $\mathrm{z}$ ich twórczością. Podobnie, jak w poprzednim przypadku, zadanie to zrealizował głównie $\mathrm{w}$ dwóch artykułach, lecz i w pozostałych tekstach pojawiały się elementy odnoszące się do twórczości wybitnych autorytetów. Nawroczyński przybliżał czytelnikowi poglądy trzech reprezentantów pedagogiki „pozytywnej”, w osobach H. Wernica, A. Dygasińskiego i J. W. Dawida; a także trzech przedstawicieli pedagogiki narodowej S. Szczepanowskiego, Z. Balickiego i L. Zarzeckiego. Autor zmierzył się również z krytyką ich twórczości oraz, na jej podstawie, zapoznawał odbiorcę $\mathrm{z}$ własnymi opiniami na temat omawianych problemów.

Z prezentowanych w tekstach myślicieli, szczególną sympatię przejawiał do dorobku naukowego L. Zarzeckiego, S. Szczepanowskiego oraz, przede wszystkim, J. W. Dawida. Oprócz zatem rzetelnej oceny ich twórczości, podkreślał istotne i, według niego, warte uwagi koncepcje pedagogiczne. Zarzeckiego wyróżnił zatem za to, iż jako pierwszy sprostał zadaniu naukowego pogłębiania podstawowych pojęć pedagogiki narodowej, stając się tym samym jej pierwszym „fachowym teoretykiem", oraz za nadanie pedagogice narodowej charakteru prospektywnego. Obie te kwestie bliskie były Nawroczyńskiemu. Jako naukowiec i pedagog dbał zawsze o dogłębną analizę i precyzowanie pojęć w swych tekstach, a także o przyszłościowe nastawienie własnych koncepcji pedagogicznych. Twórczość naukowa Zarzeckiego obejmowała również koncepcję budowy „struktury duchowej narodu” za pomocą „wyższych dóbr cywilizacji”, która od razu budzi skojarzenia z założeniami pedagogiki kultury II Rzeczypospolitej. Wszak przedstawiciele tego nurtu, a pośród nich Nawroczyński, postulowali budowę życia duchowego jednostki i jej osobowości za pomocą dóbr kultury.

Nawroczyński, podobnie jak pozostali pedagodzy okresu międzywojennego, poszukiwał harmonii w wychowaniu, odchodząc od wszelkich skrajności. Starał się znosić wszelkie antynomie pedagogiczne, nad którymi dosyć dużo dywagowali pedagodzy jego czasów. Dlatego też zapewne Szczepanowski zyskał sobie jego przychylność dzięki połączeniu romantyzmu i pozytywizmu w życiu duchowym człowieka, czyli odnalezieniu „złotego środka” między idealizmem i realizmem 
w wychowaniu. Podobnie efektem walki ze skrajnościami był główny cel wyznaczony przez Szczepanowskiego dla Polski: „Utrzymać zasadę wolności, a jednocześnie wytworzyć silną i karną organizację życia społecznego". Zatem i tym prawdopodobnie myśliciel owy zaskarbił sobie uznanie Nawroczyńskiego, który nazwał jego pedagogikę: ,,pedagogiką najwyższego wysiłku i bohaterstwa”.

Spośród omawianych myślicieli wyróżniał zwłaszcza J. W. Dawida, który według niego jako jedyny, w pełni ,zmierzył się” z pozytywizmem i wypracował własny system pedagogiczny, choć dodawał, że „Dawid jest osobowością, która się cała nie da zamknąć w żadnym prądzie, w żadnej doktrynie"10. Autor wyraził również podziw dla tegoż naukowca za pionierskie na gruncie polskim i jedne z nielicznych w Europie, badania związane z pedagogiką eksperymentalną. Podkreślił także jego dokonania pedagogiczne w postaci utworzenia własnej szkoły i wychowania znamienitych następców, z których szczególnie wyróżniła się znana na gruncie pedagogiki Aniela Szycówna.

Trzecim i ostatnim problem, jaki poruszył w swych artykułach Nawroczyński, było zagadnienie dotyczące kształcenia nauczycieli. Zajmowało ono wyjątkowe miejsce w dorobku tego myśliciela z racji jego praktyki zawodowej. Kwestii tej poświęcił w głównej mierze jeden artykuł w „Kulturze i Wychowaniu”, ale porusza ją również pośrednio definiując pedagogikę pozytywną:

Ten to kierunek był gwałtowną reakcją przeciwko teoriom pedagogicznym romantyzmu. Pojęciu misji narodowej przeciwstawił poznanie rzeczywistości. Odwracając się od idei ofiary, zalecił spełnianie codziennych, prozaicznych obowiązków. Ponad uczucie i fantazję wyniósł rozum i wolę. Pogardziwszy filozofią idealistyczną, wskazówek postępowania szukał w naukach ścisłych. Wyrzekając się walki orężnej, lepszą przyszłość kazał zdobywać przez szerzenie oświaty, podnoszenie rolnictwa, rzemiosła, przemysłu i handlu ${ }^{11}$.

Już w tych słowach możemy dopatrywać się poglądów autora, dla którego odbudowa kraju poprzez polepszenie stanu oświaty była jedną ze spraw pierwszorzędnych. Temu właśnie poświęcił przecież wiele lat swego życia zawodowego i to zadanie, jako doświadczony i twórczy nauczyciel, a także odpowiedzialny i światły pedagog, uważał za priorytetowe.

W pełni jednak kwestię kształcenia nauczycieli Nawroczyński rozwinął w artykule pod tym właśnie tytułem. Tekst ten jest najbardziej bezpośrednią wykładnią jego poglądów, dzięki czemu stanowi być może najistotniejszą, z perspektywy współtworzenia podwalin teoretycznych pedagogiki kultury, publikację na łamach „Kultury i Wychowania”.

Tematyka omawianego artykułu zamyka się w kilku postulatach określających stanowisko Nawroczyńskiego, które, m. in., próbował realizować w praktyce:

10 B. Nawroczyński, Trzej przedstawiciele pedagogiki pozytywnej w Polsce, „Kultura i Wychowanie" 1935/1936, z. 3, s. 171.

${ }^{11}$ Tamże, s. 162. 
- popierał postulat polepszenia poziomu kształcenia nauczycieli szkół średnich;

- uważał, że w kształceniu nauczycieli szkół średnich teoria powinna iść w parze z praktyką, dlatego należy organizować szkoły ćwiczeń obok uniwersytetów;

- pedagogika i dydaktyka przedmiotu, jako przedmioty wymagające wiedzy i dojrzałości, powinny być uczone na piątym roku studiów.

\section{Wkład Bogdana Nawroczyńskiego w dorobek pedagogiki kultury na lamach „Kultury i Wychowania"}

Ostatnią część swego opracowania poświęcę jeszcze jednej kwestii związanej z twórczością publicystyczną Nawroczyńskiego w „Kulturze i Wychowaniu”, a mianowicie odpowiedzi na pytanie, czy i w jakim aspekcie Nawroczyński wzbogaca swoimi artykułami pedagogikę kultury okresu II Rzeczypospolitej? Ponieważ czasopismo redagowane przez Suchodolskiego było wówczas czołowym periodykiem propagującym idee filozofii i pedagogiki kultury, zadanie to wydaje się najważniejszym $\mathrm{z}$ dotychczas przeze mnie omawianych.

W swoich publikacjach w „Kulturze i Wychowaniu” Nawroczyński wskazał pośrednio na szereg koncepcji związanych z teorią pedagogiczną. Już sam dobór tematyki artykułów jasno rysuje kierunek myśli autora, który zarówno bezpośrednio, jak i pośrednio dzieli się z czytelnikiem swymi koncepcjami pedagogicznymi.

Postulaty i koncepcje, które wysuwał na kartach omawianego periodyku Nawroczyński, to przede wszystkim:

- zniesienie antynomii pedagogicznych: idealizm a realizm, wolność a silna i karna organizacja życia społecznego;

- odbudowa kraju poprzez polepszenie stanu oświaty (związana z praktyką kształcenia nauczycieli);

• budowa „struktury duchowej narodu” za pomocą „wyższych dóbr cywilizacji”.

Można zatem sformułować wniosek, iż właśnie dzięki tym koncepcjom, twórczość Nawroczyńskiego była nieocenionym wkładem w dążenie do osiągnięcia celów „Kultury i Wychowania” oraz w, tworzące się na łamach tego czasopisma, teoretyczne podwaliny nowego nurtu, jakim w owym czasie była pedagogika kultury. 